\title{
The Effect of Teacher Competence, Discipline and Innovation in Teacher Success
}

\author{
Iis Ratisyanti ${ }^{*}$, Happy Fitria ${ }^{2}$, Syaiful Eddy ${ }^{2}$ \\ ${ }^{1}$ SD Negeri Babat Supat, South of Sumatra, Indonesia \\ ${ }^{2}$ Universitas PGRI Palembang, Indonesia \\ ${ }^{*}$ Corresponding author. Email: iisratisyanti17@gmail.com
}

\begin{abstract}
The intention of this research is to assess the impact of competence, discipline, teaching creativity on performance in the Babat Supat District of Musi Banyuasin Regency. This study was performed on teachers in the Babat Supat District of Musi Banyuasin Regency. The sample size was taken from as many as 75 teachers. The sampling technique was intended for sampling, namely where some of the teachers in the Babat Supat District, Musi Banyuasin Regency, were interviewed. Data collection was carried out by circulating questionnaires using a 5-point Likert scale to calculate 102 items of the statement. The method of analysis used is a multiple linear regression analysis. The results indicated that at the same time, disciplinary competence and teaching imagination had a substantial influence on the output of teachers.
\end{abstract}

Keywords: Competence, Discipline, Innovation, Success of Teachers

\section{INTRODUCTION}

Education is a process of training and development of knowledge, skills, thinking, character, and so on, particularly through formal education. Education is a crucial human need, because education has a responsibility to prepare human capital for the growth and advancement of the country [1]. Understanding education applies to this term, which explains the essence and aims of education, namely human beings. Person himself has many facets and a very dynamic character. Education is the most important indicator for the growth of a nation [2].

According to Sagala in Damanik [3] in the field of education, the teacher aspect is very important in achieving the educational objectives that have been set and will be achieved, so that success is very important in achieving these educational objectives. "Performance" in Indonesian is the translation of the English term, that is, the word "Performance" which means: (1) job, deeds, (2) appearance, performance. Another definition of results is as a measure of achievement in meeting predetermined objectives.

The school curriculum is a national prosperity [4]. School performance is demonstrated by measurements of how school participants view things such as benefits, certainty, fairness, working conditions, staff impressions on their supervisors, colleagues, opportunities for advancement, progress, protection, security and rewards. Output is a show of the work of an instructor. There are 11 performance measures that can be assessed: 1) commitment; 2) job performance; 3) integrity; 4) discipline; 5) innovation; 6) collaboration; 7) leadership; 8) personality; 9) initiative; 10) skills and 11) accountability [5].

Productivity is influenced, among others: 1) mental attitude (job motivation, work discipline, work ethics); 2) education; 3) skills; 4) leadership management; 5) jobs; 6) salary and health; 7) social security; 8) working climate; 9) infrastructure; 10) technology, and 11) opportunities for achievement [6].

Job discipline is one factor that can influence results. Discipline is a way to prepare and mold others to do something better. In short, it can be said that knowledge in carrying out a mission or a job [7] is a source of discipline. Teacher competence is another aspect that influences efficiency. As is well established, a teacher must have the integrity to be able to lead his students to the door of success. The competencies referred to are pedagogical competence, personal competence, technical competence and social competence.

Creativity in learning is part of a mechanism that is inseparable from being taught and educators in the learning and teaching process. In general, the key 
purpose of instructor innovation is to help complete work quickly and efficiently.

Creative teachers produce creative students [8]. Teacher creativity plays an important role in learning: (1) teacher creativity is useful in transferring more complete information; (2) teacher creativity is useful in stimulating students to think more scientifically in studying group phenomena or natural phenomena that are the focus of learning study, and (3) teacher creativity stimulates student creativity. "Creativity is the ability to change and enrich the world with inventions in the fields of technology, art, and inventions in other fields" [9].

The tendency in the field indicates that, generally speaking, teaching conduct in elementary schools is only confined to recognizing the purpose of teaching, where the teaching process is one-way from teacher to student. As a consequence, learning is often monotonous, less attractive and less inspiring, and tends to contribute to passive attitudes among students.

On the basis of the author's observations in SDN Ramba, Babat Supat District, Musibanyuasin Regency, it can be seen that the teaching standard of teachers is still not strong, that the teaching methods of teachers do not display substantial improvements, even though several training courses have taken place. Teachers often only use instructional techniques in learning and seldom use media help in learning. If you want to be a successful instructor, teachers need to improve their superiority in the teaching process by stressing the value of learning. For this purpose, teachers need to establish imaginative learning actions by seeing students not only as learning objects, but also as learning topics.

Essentially, teaching if done well is said to be innovative. The key to the success of creative creation lies in the creative and effective teaching of good interactions. This is not simple and requires the skill and imagination of learning activities to accomplish what is required. The characteristics or characteristics of creative teachers according to Pardamean include: versatile, enthusiastic, respectful, easy, humorous, encouraging, gentle, disciplined, sensitive, empathetic [10].

As an educator, teachers need to be more innovative than students. The value of creativity for a student is the importance of creativity for a teacher. The value of teacher creativity in Talajan learning, among others [11]: a) Teacher creativity is useful for growing student interest in subjects. b) Teacher imagination is useful for the more total transfer of knowledge. c) Instructor imagination is useful in enabling students to think scientifically about community phenomena or natural phenomena that are the focus of learning. d) Teacher creativity activates student creativity. Sobandi's [12] research shows that the competence of State Vocational
High School (SMKN) teachers in the field of business and management skills in the city of Bandung, consisting of pedagogical competence, technical competence, personal competence and social competence, is in a strong category.

Study conducted by Karmelia, et al. Based on the results of the research conducted in Asoka Cluster, Sungai Serut District, Bengkulu Region, the overall final results achieved were based on good criteria. As viewed from the discipline in the exercise of disciplinary duties, discipline in the service of students, discipline in the work environment and discipline in time, very good standards are met in its implementation [13]

Teacher competence is expertise, teaching skills, and discipline is compliance with the application of the method, such that these variables partially affect efficiency. Since success is essentially the knowledge of teachers in the exercise of their professional skills, in particular teaching skills and skills, in which four competencies are incorporated, namely pedagogical competence, personality competence, social competence and professional competence. Kartini et al. state that there is a substantial impact on the performance of teachers between principal leadership, instructional supervision and professional competence at the same time [14].

\section{METHODS}

This form of research is quantitative research, that is to say, research based on the study of empirical phenomena to be quantitatively studied. Quantitative analysis is a method that uses data in the form of numbers as a medium for interpreting knowledge about what you want to know. This analysis uses a lot of numbers, ranging from data collection, data interpretation and the display of test results.

The data used in this analysis are primary data, namely questionnaire data collected from teacher interviews. This research consists of two independent variables, namely competence $\left(\mathrm{X}_{1}\right)$, discipline $\left(\mathrm{X}_{2}\right)$, imagination $\left(\mathrm{X}_{3}\right)$, while the dependent variable is the output of the teacher's job (Y). Study on data collection has been performed quantitatively.

This research approach uses partial and simultaneous regression models used for analysis or hypothesis testing where the researcher aims to assess the effect or relationship of the independent variable to the dependent, where one of the independent variables is monitored (fixed). It occurred, and then, according to the backwardness, to figure out the factors that caused the incident.

The study population was all educators in the SD Negeri Se Babat Supat District, which consisted of 295 
teachers. This sample was taken by researchers using probability sampling techniques, namely sampling techniques that provide equal opportunities for each element (member) of the population to be selected as sample members) [15]. The determination of the number of samples shall be made by means of measurements using the Slovin formula.

Based on the Slovin formula, the number of test samples obtained is 75. Sample, guy. The sample obtained was 75 respondents on the basis of the above estimates. Data collection techniques in this study were carried out using questionnaires, interviews, findings or observations, examinations or tests, reports and so on. That the data collection technique which be carried out by interview, questionnaire, observation and a combination of the three. In this analysis, the data collection method used by the researcher was a questionnaire to be answered by the respondent on the basis of the circumstance, observation and documentation they encountered.

Data obtained by using the Likert scale model. The data analysis methodology used simple regression analysis and multiple regression with SPSS For Windows version 25.0.

\section{RESULTS AND DISCUSSION}

\section{Effect of Teacher Performance Competence}

The pattern of relationship between teacher competence and teacher success is represented in the form of the regression equation $\mathrm{Y}=72.825+0.373 \mathrm{X}_{1}$.

Based on the significance test of the school culture variable on the output of teachers in SD Negeri in Babat Supat District, the $t$ value is $97.841>$ the $t$ value of the table is 1.9930 , where the $\mathrm{t}$ value is greater than the $\mathrm{t}$ value of the table and the 0.000 value is less than 0.05 . Ho1 is acknowledged in such a way that there is a major impact between teacher competence on teacher success in SD Negeri in the Babat Supat district.

Teacher competence is a set of qualities that must be present in teachers in order to realize their success in an acceptable and successful manner. Teacher skills include: intellectual competence, physical competence, personal competence, relational competence and moral competence.

Competencies are graded from simple or basic to more complicated or complex levels which, in turn, are linked to the preparation of materials or learning experience, which typically consists of: (1) mastering a minimum of basic skills; (2) basic skills practice; and (3) improving or enhancing skills or skills. The three processes will proceed as long as there is always a chance to strengthen or grow their skills.
Teachers in the district of Babat Supat should develop their competence. Teachers' expertise can be strengthened by engaging in a number of trainings, seminars or courses, and even continuing to learn in order to expand their skills. Increased capacity would improve the expertise of teachers, for example, to better master the subject matter, to better master and diagnose student behavior, to better carry out the teaching process and to assess the outcomes of student work.

This is in line with the research by Susti Marce et al [16]. It was noticed from the results of the research that: 1) policy formulation; 2) arrangement of the Principal of SDN 3 Babat Toman shall be carried out by the Principal by separating tasks according to the expertise of their respective fields, 3) supervision of the Principal of SDN 3 Babat Toman shall be carried out directly by teachers and students during the morning break, monitoring the activities of students and teachers by monitoring each class.

This is in line with the research conducted by Marlina et al [17] which explores the impact of managerial competence of principals and instructional supervision on teacher performance. The findings of this study suggest that: 1) the main managerial competence has a major impact on the output of teachers; 2) there is a significant effect of academic supervision on the performance of teachers; and 3) there is a significant effect of key managerial competence and academic supervision on the performance of teachers. The inference is that the key managerial competence and academic supervision have a substantial influence on the success of teachers at SMA Negeri 3 Martapura.

Suratman's et al [18] study entitled The Impact of Principal Leadership and Teacher's Competence against Teacher Success in Indonesia. The findings obtained in this study 1) there is no impact on the performance of the teacher by principal leadership; 2) there is an effect of the competence of the teacher on the performance of the teacher; and 3) there is at the same time an effect of the principal leadership and competence of the teacher on the performance of the teacher. This paper contributes to enhancing the performance of teachers through principal leadership and the skill of teachers.

\section{The effect of the teaching discipline on the output of teachers}

The pattern of the relationship between teacher discipline and teacher success is represented in the form of the regression equation $\mathrm{Y}=38.963+0.677 \mathrm{X}_{2}$.

Based on the significance test of the discipline variable on the performance of teachers in SD Negeri in Babat Supat District, the $\mathrm{t}$ value is $8.862>$ the $\mathrm{t}$ table price is 1.9930 where the $t$ value is greater than the $t$ table and the 0.000 value is less than 0.05 , so Hol agreed that there is a major effect between the teaching discipline on the performance of teachers in SD Negeri. 
Sutrisno [19] claims that teaching discipline is an organized and orderly requirement that teachers in schools have no violations that can directly or indirectly harm themselves, their colleagues and the school as a whole, so that it can contribute to the growth of the personality of students as a whole. Systematic and pragmatic, so that they can live according to Islamic teachings, so that happiness in the world and the afterlife can be created.

Educator discipline is an attitude full of willingness to comply with all the laws and norms that occur in the performance of their duties as a sense of accountability for the education of their students. Because, after all, the teacher or educational staff (employee) is a mirror for their students in their attitude or role model.

This means that teachers in the Babat Supat Subdistrict, Musi Banyuasin Regency, must strengthen their discipline because good discipline would dramatically improve the performance of teachers. Teachers are expected to provide the learning group at school with examples of discipline. Students would be more excited about receiving lessons if they provide their students with examples of high discipline.

This is in line with the study of Alhusainiet al [20]. The findings show that: 1) there is a significant impact of work motivation on the performance of teachers; 2) there is a significant impact of work discipline on the performance of teachers; 3 ) there is a major impact on the success of teachers between job encouragement and work discipline.

This research was also sponsored by Muhammad Dahlan, Yasir Arafat, and Syaiful Eddy 2020. The findings showed that: 1) there was a significant impact of school culture on the performance of teachers in the SD Negeri Sungai Lilin District; 2) there was a significant impact of education and training on the performance of teachers in the SD Negeri Sungai Lilin District; 3) there was a significant impact of school culture and education and training on the performance of teachers in the SD Negeri Sungai Lilin District [21].

Hadiati's research The Effect of Work Discipline on MTs Performance in Paddy Lampung states that, based on the results of the presentation and analysis of the data, it is concluded that the work discipline has a positive and important impact on the performance of MTs in Paddy Lampung [22].

\section{The Effect of Teacher Creativity on Teacher Success}

The pattern of the relationship between teacher discipline and teacher success is represented in the form of the regression equation $\mathrm{Y}=51.188+0.567 \mathrm{X}_{3}$.

Based on the significance test of the innovative variable on the performance of teachers in SD Negeri in Babat Supat District, the $t$ value is $8.779>$ the $t$ table price is 1.9930 where the $\mathrm{t}$ value is greater than the $\mathrm{t}$ table and the significance value is 0.000 less than 0.05 , so Ho1 agreed that there is a major effect on the performance of teachers in SD Negeri Babat Supat District.

Creativity is the ability to build new combinations on the basis of existing data, knowledge, or elements. Second, innovation (creative thinking or divergent thinking) is a capacity based on available data or knowledge. Third, organizational innovation can be formulated as a capacity that represents fluency, versatility (flexibility) and originality of thought, as well as the ability to elaborate (develop, enrich, detail) ideas.

By innovative thinking, teachers are encouraged to be more open and divergent, ensuring that they are not necessarily linked to existing things, making it easier to consider change and creativity.

Teachers' innovation in teaching must involve a variety of concepts, such as providing convenience and a happy atmosphere, creating a favorable learning environment, attracting interest, presenting relevant content, involving positive learning feelings, involving all senses and thoughts, and adapting to the level of ability.

For this reason, teachers in the Babat Supat District should be able to increase their creativity in the learning process. A friendly atmosphere of learning for students is an enjoyable experience. They are students who are more interested in learning approaches that are not monotonous and tiresome. For this purpose, the teacher's imagination is supposed to enhance the performance of the teacher.

Lakoy's [23] research entitled The Influence of Communication, Group Cooperation and Creativity on Employee Performance at the Aryaduta Manado Hotel notes that the creativity in this study shows that creativity has a major impact on the performance of employees at the Aryaduta Manado Hotel. This means that innovation is one of the factors or variables that can affect and boost the output of employees employed at Hotel Aryaduta Manado.

Alisyahbana et al's research on the influence of creativity and teamwork on the performance of uppkh companions (the implementation unit of the hope family program) in Sampan Regency states that, based on testing the first hypothesis of this report, it is hypothesized that creativity and teamwork have a simultaneous and important impact on the performance of employees [24].

Teachers' innovation in teaching must involve a variety of concepts, such as providing convenience and a happy atmosphere, creating a favorable learning environment, attracting interest, presenting relevant content, involving positive learning feelings, involving 
all senses and thoughts, and adapting to the level of ability.

\section{The effect of teaching discipline, competence and imagination on the success of teachers}

The model of the relationship between school culture and the organizational commitment to teacher success is represented in the form of the regression equation $\mathrm{Y}=40,513+0,0,202 \mathrm{X}_{1}+00,239 \mathrm{X}_{2}+$ $0,219 X_{3}$, which implies that the performance of teachers increases positively with the discipline, competence and imagination of teachers.

On the basis of the test of significance of the component discipline, skill and imagination of the teachers, along with the success of the teachers in SD Negeri in Babat Supat District, it was found that the $\mathrm{f}$ value was $40.183>$ the price of the $\mathrm{f}$ table was 2.73 where the measured $f$ value was greater than the $f$ table and the value of significance 0.000 which is less than 0.005 than the Ho3 value is acknowledged.

Improved attempts should be made to increase the competence of teachers, increase the discipline of teachers and increase the innovation of teachers. Strong teacher skills will improve performance, high discipline will also improve teacher performance and, of course, high innovation will also improve overall teacher performance.

Research by Riwan Sigalingging et al [25] with the title Impact of Encouragement, Management Competence and Work Environment on Teacher Success through Work Discipline. Results have shown that encouragement, managerial competence, the working environment have an impact on the performance of teachers through the discipline of work. Managerial competence is capable of increasing encouragement that affects the success of teachers through the discipline of work. The job environment is too convenient for teachers to be less inspired. Motivation, managerial competence and the working atmosphere may have an effect on teacher success through the SMP and SMA Budi Mulia Jakarta-Bogor job disciplines.

This research was also sponsored by Yopi Aprida, et al [26]. The influence of the key supervision and the encouragement of the teacher work together on the output of the teachers in SMP Negeri, West Prabumulih District. The population of this study was 104 teachers at the State Junior High School in the West Prabumulih Subdistrict who were used for the survey. Data were collected using the Likert scale questionnaire, analyzed using correlation and regression techniques using the Statistical Program for Social Sciences (SPSS) version 22.0 and the Manual. This research found that 1) the impact of school principal supervision on the output of teachers in SMP Negeri Se Prabumulih Barat was 52.6 per cent, while the remaining 47.4 per cent was affected by other factors which were not variable in this study. 2) The impact of teacher motivation on teacher performance in the SMP Negeri Se Prabumulih Barat District is 46.2 per cent, while the remaining 53.8 per cent is affected by other variables that are not variable in this study 3 ) the effect of primary supervision and the motivation of teachers to work together is the same as the performance of teachers in the State Junior High School in West Prabumulih Subdis.

\section{CONCLUSION}

Based on the findings of the data analysis, the effect of teacher competence, teacher discipline and teacher imagination both partly and concurrently on teacher performance can be described as follows: 1) there is a strong and significant influence of teacher competence on teacher performance in part so that it can be inferred that the first hypothesis is accepted; 2) the effect of teacher discipline on teacher output is partially important, so that it can be assumed that the first hypothesis is accepted; 3) there is a significant and significant impact on teacher creativity on teacher performance in part so that it can be assumed that the first hypothesis is accepted; and 4) there is a significant and significant influence on teacher competence, teacher discipline and teacher creativity to influence teacher performance at the same time so that it can be concluded that the hypothesis starts.

\section{ACKNOWLEDGMENTS}

Thank you very much to the Principal and Teacher Board of SD Negeri Babat Supat. It was also forwarded to the Chancellor, Postgraduate Director, Head of Education Management Study Program, Advisor I, Supervisor II and all postgraduate lecturers at PGRI Palembang University. Also, for all fellow graduate students of PGRI Palembang University. Thank you for helping to complete this journal, which is the result of the preparation of the thesis as a prerequisite for the final report. Please criticize and recommend to develop this journal.

\section{REFERENCES}

[1] Handayani, D. O., Kristiawan, M., \& Destiniar. (2020). Education and Training for Strengthening Principal to Effective Schools. International Journal of Progressive Sciences and Technologies (IJPSAT), 22(1), 321-326.

[2] Asvio, N., Yamin, M., \& Risnita. (2019). Influence of Leadership Style, Emotional Intelligence and Job Satisfaction toward Organizational Commitment (Survey at SMA Muhammadiyah South Sumatera). International Journal of Scientific \& Technology Research 8 (8). 
[3] Damanik, R. (2019). Pengaruh Disiplin Kerja Terhadap Kinerja Guru [The Effect of Work Discipline on Teacher Performance]. Jurnal Serunai Ilmu Pendidik., vol. 5, no. 2.

[4] Maseleno, A., Ayshwary, B., Ivanova, T. N., Hashim, W., Nguyen, P. T., Shankar, K., Kristiawan, M., Huda, M. (2019). General Theoretical and Philosophical Aspects of Modern Education. Aspectos Teóricos y Filosóficos Generales de la Educación Moderna. Revista San Gregorio 2019, No. 32 Special Issues August.

[5] Komariah, A., \& Cepi, T. (2010). Visionary Leadership Menuju Sekolah Efektif [Visionary Leadership Towards Effective Schools]. Jakarta.: Bumi Aksara.

[6] Sedarmayanti. (2015). Manajemen Sumber Daya Manusia [Human Resource Management]. Bandung: Refika Aditama.

[7] Anoraga, P. (2014). Psikologi Kerja [Psychology of Work]. Jakarta.: Rineka Cipta.

[8] Hanim, H., \& Rahmadoni, J. (2020). Determination of Lecturer Reception Using Analytical Hierarchy Process (AHP). Journal of Applied Engineering and Technological Science (JAETS), 1 (2), 136141.

[9] Munandar, U. (2004). Pengembangan Kreativitas Anak Berbakat [Talented Child Creativity Development]. Jakarta.: Gramedia.

[10] Perdamean, T. (2004). Profesionalitas Guru Perlu Daya Kreativitas [Teacher Professionalism Needs Creativity Power]. Bandung: Alfabeta.

[11] Talajan, G. (2012). Menumbuhkan Kreativitas dan Prestasi Guru [Fostering Teacher Creativity and Achievement]. Yogyakarta: Laksbang Presindo, 2012.

[12] Sobandi, A. (2010). Pengaruh kompetensi guru terhadap kinerja mengajar guru smkn bidang keahlian bisnis dan manajemen di kota Bandung [The influence of teacher competence on teaching performance of junior high school teachers in the field of business and management expertise in the city of Bandung]. Manajerial, vol. 9, no. 7, pp. 25$34,2010$.

[13] Karmelia, I., \& Rosa, N. (2019). Pelaksanaan Kedisiplinan Guru PAUD Di Gugus Asoka [Discipline Implementation of PAUD Teachers in the Asoka Cluster]. Jurnal Ilmu Potensia, vol. 4, no. 2, pp. 161-170.

[14] Kartini, D., Kristiawan, M., \& Fitria, H. (2020). The Influence of Principal's Leadership, Academic Supervision, and Professional Competence toward
Teachers' Performance. Education and Training for Strengthening Principal to Effective Schools. International Journal of Progressive Sciences and Technologies (IJPSAT), 20(1).

[15] Sugiyono. (2016). Metode Penelitian Kuantitatif, Kualitatif dan R\&D [Quantitative Research Methods, Qualitative and $R \& D]$. Bandung: PT Alfabet.

[16] Marce, S., Ahmad, S., \& Eddy, S. (2020). Manajemen Kepemimpinan Kepala Sekolah Sebagai Administrator Dalam Peningkatan Kompetensi Guru [Leadership Management of School Principals as Administrators in Improving Teacher Competence]. Dawuh Islam. Educ. J., vol. 1, no. 2, pp. 76-81.

[17] Marlina., Ahmad, S., \& Eddy, S. (2020). Analisis Kinerja Penilik Pendidikan Nonformal di Dinas Pendidikan dan Kebudayaan Kabupaten Musi Banyuasin [Analysis of the Performance of Nonformal Education Inspectors at the Education and Culture Office of Musi Banyuasin Regency]. $J$. Al-Qiyam, vol. 1, no. 1, pp. 1-10.

[18] Suratman., Arafat, Y., \& Eddy, S. (2020). The Influence of Principal's Leadership and Teacher 's Competence toward Teacher's Performance in Indonesia. vol. 1, no. 20, pp. 96-104.

[19] Sutrisno, E. (2014). Manajemen Sumber Daya Manusia [Human Resource Management]. Jakarta.: Kencana Prenada Media Group.

[20] Alhusaini, A., Eddy, S., \& Kristiawan, M. (2020). Pengaruh Motivasi Kerja dan Disiplin Kerja terhadap Kinerja Guru. J. Pendidik. Tambusai, vol. 4, no. 3, pp. 2166-2172.

[21] Dahlan, M., Arafat, Y., \& Eddy, S. (2020). Pengaruh Budaya Sekolah dan Diklat terhadap Kinerja Guru. J. Educ. Res., vol. 1, no. 3, pp. 218 225.

[22] Hadiati, E. (2018). Pengaruh Disiplin Kerja terhadap Kinerja MTs Se-Kota Bandar Lampung [The Effect of Work Discipline on MTs Performance in Bandar Lampung City]. Al-Idarah J. Kependidikan Islam, vol. 8, no. 1, pp51-65.

[23] Lakoy, A. C. (2015). Pengaruh Komunikasi, Kerjasama Kelompok, Dan Kreativitas Terhadap Kinerja Karyawan Pada Hotel Aryaduta Manado [The Influence of Communication, Group Cooperation, and Creativity on Employee Performance at Hotel Aryaduta Manado]. Jurnal EMBA, vol. 3, no. 3, pp. 981-991.

[24] Alisyahbana., Farid, I., Wispandono, I., \& Moch, R. M. (2015). "Pengaruh Kreativitas Dan 
Kerjasama Tim Terhadap Kinerja Pendamping Uppkh (Unit Pelaksana Program Keluarga Harapan) Kabupaten Sampang [The Influence of Creativity and Teamwork on the Performance of Uppkh Facilitators (Implementation Unit of the Hope Family Program) Sampang Regency]. Jurnal Neo-bis, vol. 9, no. 2, pp. 54-78.

[25] Sigalingging, R., Supriyadi, E., Putriana, L. (2019). Pengaruh Motivasi, Kompetensi Manajerial, Dan Lingkungan Kerja Terhadap Kinerja Guru Melalui Disiplin Kerja [he Influence of Motivation, Managerial Competence, and Work Environment on Teacher Performance through Work Discipline]. Ekobisman, vol. 4, no. 2, pp. 2597-9302.

[26] Aprida, Y., \& Fitria, H., \& Nurkhalis. (2020). Pengaruh "Supervisi Kepala Sekolah dan Motivasi Kerja Guru Terhadap Kinerja Guru [Principal Supervision and Teacher Work Motivation on Teacher Performance]. Jurnal of Education Research page 160-164. 